\title{
Kajian Visual Busana Tari Topeng Tumenggung Karya Satir Wong Bebarang Pada Masa Kolonial
}

\author{
Anis Sujana \\ Institut Seni Budaya Indonesia (ISBI) Bandung \\ Jl. Buah Batu no 212 Bandung
}

\begin{abstract}
Cirebon mask refers to a traditional dance genre that shows dancing repertoar: one of it is the Tumenggung (Mask) Dance. Observed from its costume, Tumenggung Dance costume elements are believed "out" of the ordinary (conventional) Cirebon Mask Dance. This is indicated by the usage of bendo/udeng(headcloth commonly used by men as head accessory), pet/hat, sun glasses, and a complete set of formal clothes with tie. This research aims in explaining the meaning behind the costume of Tumenggung Dance, with its various local cultural attributes attached. This research uses qualitative method with cultural historical approach. Diacronically it is focused in colonial period in Java Island, and sincronically, on the symbolic meaning of the costume of Tumenggung Dance. The Visual analysis is conducted through perspective of Pierce semiotic theory that offers trikotomi reasoning: sign -referent - interpretant. Based on the result of the analysis shows that Tumenggung Mask Dance has a connotative meaning, such as it was acted out as satire from the common people to the authority in that time. In the context of art tradition during the colonialisation period, the research shows that, the costume of the Tumenggung Mask Dance posseses double codes type in the same manner as sign characteristic in the post-modern science.
\end{abstract}

Keywords: Cirebon Mask Dance, Tumenggung Mask dance costume, Semiotics code and sign

\begin{abstract}
ABSTRAK
Topeng Cirebon menunjuk kepada suatu genre pertunjukan tradisional yang menampilkan beberapa repertoar tari: salah satunya adalah Tari (Topeng) Tumenggung. Dilihat dari sisi busana, elemen-elemen busana Tari Tumenggung dipandang 'keluar' dari kelaziman (konvensi) busana Topeng Cirebon, terindikasi dari pemakaian bendo/udeng, pet/topi, kacamata, kemeja lengkap dengan dasi. Penelitian ini bertujuan menjelaskan makna di balik tanda-tanda busana Tari Topeng Tumenggung, dengan berbagai atribut kelokalan budaya yang menyertainya. Penelitian ini menggunakan metode kualitatif dengan pendekatan sejarah-kebudayaan. Secara diakronik difokuskan pada periode kolonial di Pulau Jawa, dan secara sinkronik difokuskan pada makna simbolik busana Tari Tumenggung. Analisis-visual dilakukan melalui perspektif teori semiotik Peirce yang menawarkan nalar trikotomi: sign - referent - interpretant. Berdasarkan hasil analisis menunjukkan Topeng Tumenggung memiliki makna konotatif antara lain sebagai sindiran rakyat jelata terhadap penguasa pada waktu itu. Dalam konteks seni tradisi masa kolonial hasil penelitian menunjukan bahwa, busana Tari Tumenggung memiliki tipe kode-kode ganda sebagaimana karakter tanda pada bingkai keilmuan posmodern.
\end{abstract}

Kata kunci: Tari Topeng Cirebon, Busana Tari Topeng Tumenggung, semiotika kode dan tanda 


\section{PENDAHULUAN}

Topeng Cirebon, dikenal sebagai suatu jenis pertunjukan tradisional di kalangan masyarakat Cirebon dan sekitarnya. Disebut topeng karena pelaku per-tunjukannya mengenakan topeng (kedok), sedang disebut Topeng Cirebon karena Cirebon dipandang sebagai wilayah cikal bakal penyebaran topeng tersebut.

Menurut Pigeaud (1938:109-113), Topeng Cirebon yang dikenal sekarang merupakan perubahan dari pertunjukan 'topeng-besar' (groot maskerspel)yang hidup dilingkungan istana/keraton. Perubahannya menjadi 'topeng-kecil' (klein maskerspel) diduga berhubungan dengan kebutuhan praktis-pragmatis, karena pada kenyataan sekarang genre yang satu ini hidup di luar lingkungan keraton, jelasnya di kalangan rakyat. Kemudian, perubahan dari topeng-besar ke topeng-kecil ini bukan saja terbatas pada perubahan dari dramatari topeng menjadi 'tari-tarian lepas bertopeng', tetapi juga mencakup perubahan pada pelbagai aspeknya. Misalnya, aspek tokoh peran(dalam cerita) yang pada awalnya dalam jumlah besar lama kelamaan berkurang dan terbatas pada tokohtokoh utama saja. Demikian pula penataan dan penggubahan pada aspekk oreografi, musikal, dan artistik yang pada awalnya dipandang rumit pada perkembangan kemudian menjadi bentuk-bentuk yang sederhana (atau sebaliknya). Bersangkutpaut dengan perubahan-perubahan tersebut Duverger (1989: 28) menyatakan bahwa tidak ada generasi yang puas terhadap warisan yang diterimanya di masa lalu, yang oleh sebab itu pasti mereka akan memberikan sumbangannya sendiri.

Sejalan dengan asumsi di atas, maka bentuk pertunjukan Topeng Cirebon sekarang pada kenyataannya merupakan fragmen-fragmen atau babak-babak dari 'bentuk tari kiprahan' beberapa tokoh utama dalam siklus Panji.Satu suguhan babak artinya satusuguhan tarian. Tariantarian tersebut diantara-nya Tari Panji, Tari Pamindo, Tari Rumiang, Tari Tumenggung, dan Tari Klana. Sesuai dengan penamaannya Tari Panji menggambarkan tokoh Panji sebagai Raja Kediri, Tari Pamindo (dari pa dan mindo, secara harfiah adalah ke dua), menggambarkan tokoh yang memiliki karakter agak lincah (ganjen); Tari Rumiang (dari um dan riang, secara harfiah adalah riang, gembira), meng-gambarkan tokoh yang memiliki karak-ter lincah dan genit; Tari Tumenggung menggambarkan tokoh Tumenggung yang memiliki karakter kuat dan gagah, dan Tari Klana menggambarkan tokoh Klana sebagai Raja Blambangan yang memiliki sifat angkara murka. Sesuai dengan sebutannya (yaitu Tari Topeng), setiap repertoar tari tersebut mengena-kan topeng (kedok) dengan warna dan raut muka satu sama lain berbeda karena disesuaikan dengan watak/karakter dari tokoh yang ingin digambarkan.

Dalam bentuk pertunjukan sebagaimana dipaparkan di atas, oleh masyarakat Cirebon pertunjukan topeng difungsikan sebagai sarana pemujaan leluhur, media hiburan masyarakat, dan sumber penataan tari bagi generasi penerusnya. Kemudian, oleh segenap penggiatnya topeng dijadikan sebagai sarana mata pencaharian dan juga sarana memperluas kesempatan lapangan kerja (Surjaatmadja, 1980:32-36). Selanjutnya dapat ditambahkan bahwa pada masa permulaan Islam di tanah Jawa, Topeng Cirebon difungsikan sebagai sarana penyebarluasan agama Islam (ibid).

Berbeda dengan repertoar-repertoar tari lainnya, Tari Topeng Tumenggung mengenakan busana khas dengan penutup kepala berupa topi, berdasi, dan berkacamata. Selain itu juga tampil secara duet 
(acting, dialog, dan perang) bersama tokoh Jinggananom yang penampilannya digambarkan 'berantakan'. Bagaimana kode seni yang terkandung dalam busana Tari Tumenggung dan siapakah sesungguhnya tokoh Tumenggung yang ingin digambarkan dalam Tari Tumenggung, adalah permasalahan yang akan dikaji dalam penelitian ini.

\section{METODE}

Penelitian ini menggunakan metode kualitatif dengan pendekatan sejarahkebudayaan. Secara diakronik difokus-kan pada periode kolonial di Pulau Jawa, dan secara sinkronik difokuskan pada makna simbolik busana Tari (Topeng) Tumenggung. Analisis visual dilakukan dengan menerapkan teori kode ganda yang oleh Piliang (2003:187-194) dipilah ke dalam empat: pertama, kecende-rungan 'pastische', yaitu karya seni yang disusun dari elemenelemen seni yang dipinjam dari berbagai sumber masa lalu; ke dua, kecenderungan 'hibrid' (hybrid) yang mengandung di dalam dirinya "...dua ucapan, dua cara berbicara, dua gaya, dua bahasa, dua cakrawala semantik dan aksiologis"; ke tiga, kecenderungan 'parodi' (parody), yang mengarah pada 'permainan' dan 'kelucuan' (fun); ke empat, kecende-rungan 'bricolage' atau 'eklektik' (eclectic) yang digunakan untuk menjelaskan “...kombinasi fragmenfragmen kutipan dari karya-karya lain di dalam sebuah karya seni, bricolage di-

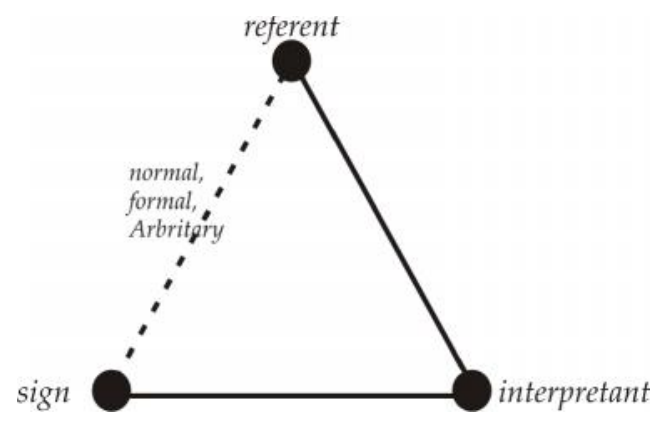

bangun oleh 'penjajaran' (juxtaposition) atau 'montase' (montage) elemen-elemen yang ada tanpa ada upaya mengolah melalui persilangan atau 'perkawinan' estetik.

Kemudian dalam menganalisis mak-na tandadilakukan melalui perspektif teori semiotik Peirce yang menggunakan nalar trikotomi (triadic) sign - referent - interpretant. Hubungan antara sign dan referentnya mempunyai tiga sifat per-talian, yaitu normal, formal, dan arbritary yang menghasilkan tiga tanda yang berbeda pula, yaitu index, icon, dan symbol (Spradley dan Zoest dalam Munandar 2011:260). Secara sederhana digambarkan pada bagan berikut ini:

\section{HASIL DAN PEMBAHASAN}

\section{Pejabat Pribumi pada Masa Kolonial}

Masa kolonial ditandai oleh masa sulitterutama di tingkat rakyat, khususnya golongan petani.Rasa tidak puas di antara para petanidisalurkan bukan hanya terhadap penguasa kolonial tetapi juga terhadap aristokrasi pribumi yang serba kuasa termasuk kepemimpinan desa setempat (Antlov, 2001:6).

Bupati (Regent) adalah aristokrasi pribumi. Berbeda dengan masa sebelumnya, pada masa kolonial kedudukan mereka tidak lebih daripada pegawai dan pelayan pemerintah Belanda (binejsland bestuur) yang digaji. Mereka menunjukkan kesetiaan yang tidak goyah kepadanya dan memberikan pelayanan dalam menjalankan pemerin-tahan kolonial (Kartodirdjo, 2001:141). Dengan penghapusan daerahdaerah upeti di tahun 1867 dan dengan peng-hapusan panchen atau kerja wajib di tahun 1882, regenten (bupati-bupati Jawa) telah menjadi tidak lebih daripada pejabatpejabat yang digaji dalam pemerintahan Kolonial Belanda. Regent yang telah memperagakan kesetiaannya yang kuat 
dan melaksanakan pela-yanannya dengan sangat memuaskan dan menguntungkan pemerintah Belanda, menerima gelar-gelar kehor-matan yang tinggi seperti pangeran, adipati, atau aria (Scherer, 1985: 34-35).

Di sisi lain, pejabat yang langsung berhubungan dengan rakyat adalah kepala desa. Mengutip Boomgard, Maurer (dalam Antlov, 2001:133-136) mengatakan bahwa sejak tahun 1813 (masa pemerintahan Raffles), kepala desa dianggap sebagai pejabat utama pemerintahan dengan tugas pendapatan (pajak) pemerintah. Birokrat desa ini hampir di mana saja termasuk golongan sosial tertinggi di masyarakat pedesaan, status sosial mereka sangat erat dengan kekuasaan politik dan kekayaan di bidang ekonomi. Sumber kekayaan ini tergambar pada pemberian kompensasi berupa tanah bengkok yang luas. Bahwa seorang kepala desa sering dan masih disebut 'raja desa'.

Di Jawa Barat kepemimpinan desa di bawah Preangerstelsel (Program Belanda dalam hal penanaman kopi paksa, sekitar tahun 1730-1870) memiliki ciri kepemimpinan otoriter. Di wilayah Cirebon, desa dikepalai oleh seorang kuwu yang dari segi ekonomi tergolong sugih.Sewaka (dalam Ramlan,2008:42) mengatakan bahwa di daerah Ciledug (Kuningan, dekat Cirebon) pada waktu itu kedudukan kuwu (kepala desa, pen.) di masyarakat desa adalah sesuatu yang sangat istimewa, tidak ubahnya sebagai 'raja kecil'.

\section{Istilah Tumenggung sebagai Gelar Kebangsawanan Bupati}

Di Jawa bagian Barat, selain pangeran, adipati, atau aria, istilah tumenggung menunjuk juga kepada gelar yang dipakai oleh umumnya yang berkedudukan bupati (Lubis, 2000: 315-320). Bersangkut-paut dengan hal ini pada masa lampau dikenal nama-nama seperti: R. Tmg. Wiranatakusumah, R. Tmg. Wiraminangun, R. Tmg. Ardi-kusumah, R. Tmg. Anggadireja (Bandung), R. Tmg. Suriadilaga dan Tmg. Aria Suria Kusumah Adinata (Sumedang), R. Tmg. Wiradadaha dan R. Tmg. Sacapati (Sukapura/Tasik-malaya), R. Tmg. Wiranegara (Cianjur), R. Tmg. Jayengpati Kertanegara, R Tmg. Natanagara, R. Tmg. Wiradikusumah, R. Tmg. Aria Sunarya (Galuh/Ciamis), R. Tmg. Wangsareja, R. Tmg. Wangsadireja (Limbangan/Garut)

\section{Bentuk dan Gaya Busana Masa Kolonial}

Masa kolonial ini ditandai pula oleh mulai masuknya pengaruh modernisasi. Kolonialisme yang pada awalnya bertujuan perluasan kekuasaan dan ekonomis pada gilirannya berbuntut pada penyebaran kebudayaan, dansalah satunya adalah cara berpakaian. Menurut Lombard (1996:156) di Nusantara, sejarah pakaian tak pelak lagi meng-ungkapkan pengaruh Eropa yang jelas. Pertama-tama perlu dikemukakan diterimanya pakaian Barat oleh kaum lelaki di kota-kota, dan makin lama makin banyak di pedesaan pula artinya dalam kehidupan sehari-hari bercelana panjang dan kemeja, dan pada upacara berpakaian lengkap, dengan jas dan dasi.

Bersangkut-paut dengan pengaruh pakaian ini, dekade pertama abad ke-20 muncul gejala De Europeesche Kleederdracht (pendekatan gaya ber-pakaian Eropa). Awalnya terbatas pada murid sekolah Belanda, tetapi pada tahun 1930-an beberapa bupati sudah terbiasa memakai pantalon. Khusus dalam pemakaian tutup kepala ditemu-kan fenomena pemakaian tutup kepala (bendo) yang dirangkap dengan dudukuy catokaya hidup para bupati (menak luhur) ini pada gilirannya menjadi titik orientasi gaya hidup menak leutik. Tak 
heran apabila cara berpakaian para pejabat di pedesaan mengikuti cara berpakaian golongan pejabat yang ada di atas mereka.

\section{Petani dan Wong Bebarang}

Pada masa yang sama (masa kolonial), sisa-sisa feodal masa lampau tidak banyak mengubah nasib petani. Demikianlah masyarakat terbagi lagi ke dalam dua golongan, yaitu priyayi sebagai kelas atasan dan wong cilik sebagai kelas bawahan. Desa ialah tempat tinggal wong cilik dan kota tempat tinggal priyayi(Kuntowijoyo, 1994: 4).

Di Cirebon, genre topeng-kecil hidup di pedesaan, jelasnya di lingkungan seniman dan masyarakat pedesaan yang mayoritas berstatus petani. Pada musim paceklik (kemarau panjang) petani yang berstatus seniman terbiasa melakukan bebarang yaitu mempertunjukan topeng secara berkeliling, artinya berpindah- pindah tempat, baik dalam satu desa maupun antar desa bahkan antar kota. Jangkauan bebarang ini bahkan sampai ke tanah Priangan meliputi Sumedang dan Bandung. Hardouin (1855:125-132) memberitakan tentang bebarangdari Cirebon ini bahkan menjangkau wilayah Batavia (Betawi, Jakarta sekarang). Awal abad ke20 Wentar dan Koncar adalah contoh dari wong bebarang yang biasa mempertunjukan bebarang ini. Mereka berasal dari Celuwung, salah satu desa yang termasuk dalam kecamatan Palimanan sekarang. Baik di tempat asalnya (habitat) maupun di tempat-tempat baru (ngamen) bentuk yang dipertunjukkan adalah bentuk babakan.

\section{Elemen Busana \& Atribut Topeng Cirebon}

Sebagai peristiwa tari bentuk pertunjukan topeng-kecil (Topeng Cirebon) tidak lepas dari tiga elemen pokoknya yaitu

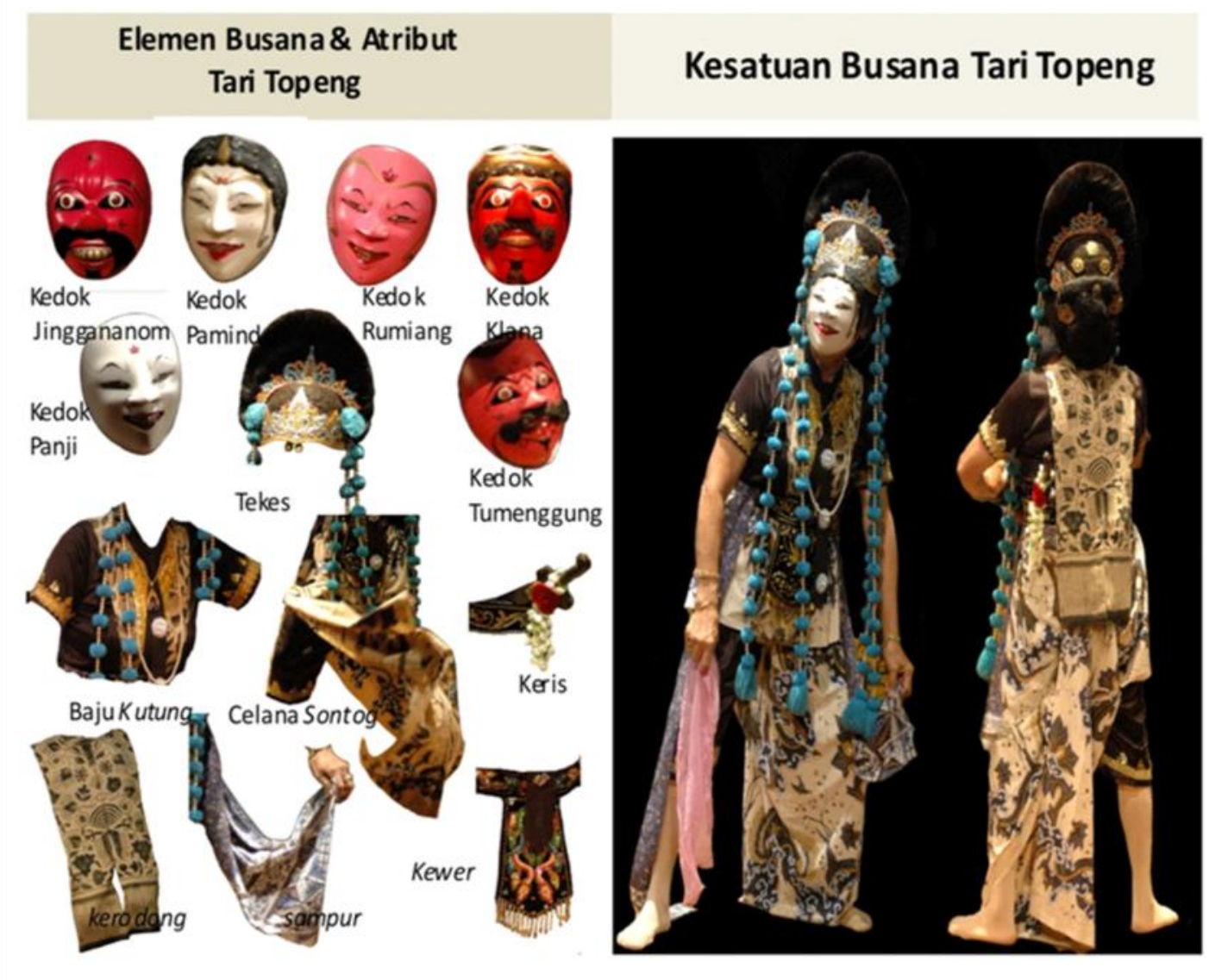

Gambar 1.

Elemen Busana \& Atribut, dan Kesatuan Busana Topeng Cirebon 
koreografi, musikal, dan artistik. Khusus mengenai artistik, lebih khusus lagi busana, Topeng Cirebon memiliki kekhasan yang ditunjukkan antara lain oleh penutup kepala yang disebut tekes (sobrah/gambuh). Pemakaian tekes ini semula seolah-olah terdapat 'pakem' di mana tokoh-tokoh yang digambarkan menggunakan tekes yang satu sama lain berbeda, sekalipun secara sekilas tampak serupa. Model suruh secandik untuk tokoh Panji, jeruk sapasi untuk tokoh Pamindo dan Rumiang, gedang saerip atau citomalik untuk tokoh Patih dan Tumenggung, dan merang sagedeng untuk tokoh Klana dan Menak Jingga.

Penutup badan, baik bagian atas maupun bagian bawah, pada kelima tarian tersebut dapat ditanggapi 'serupa'. Oleh sebab itu, dalam sebuah pertunjukan Topeng Cirebon, kelimanya dapat dibawakan secara berangkai dan sekaligus oleh seorang dalang topeng. untuk menari dengan teknik seperti itu, pada perkembangan terakhir menunjuk-kan bahwa seorang dalang cukup dengan mengganti kedok saja.

\section{Tari Topeng Tumenggung}

Dalam suatu rangkaian penyajian Topeng Cirebon, Tari Tumenggung biasanya ditempatkan pada urutan ke empat yaitu setelah Panji, Pamindo, dan Rumiang. Mengikuti pola penyajian tersebut, Tari Tumenggung dibagi ke dalam tigaadegan, yaitu: 1) tahap dodoan); 2) tahap unggah tengah; dan 3) tahap deder.Khusus pada tahap unggah tengahtokoh Tumenggung tampil duet bersama tokoh Jinggananom, dan kedua-nya terlibat dalam suatu dialog yang dilanjutkan dengan adu kekuatan.

\section{Busana Topeng Tumenggung}

Pada tahap dodoan, tokoh Tumenggung menari secara solo dengan mengenakan busana bendo/destar \& pet (topi), kacamata, baju kutung, klambi gulu, celana sontog, kerodong, kain/sinjang, sampur, kewer,

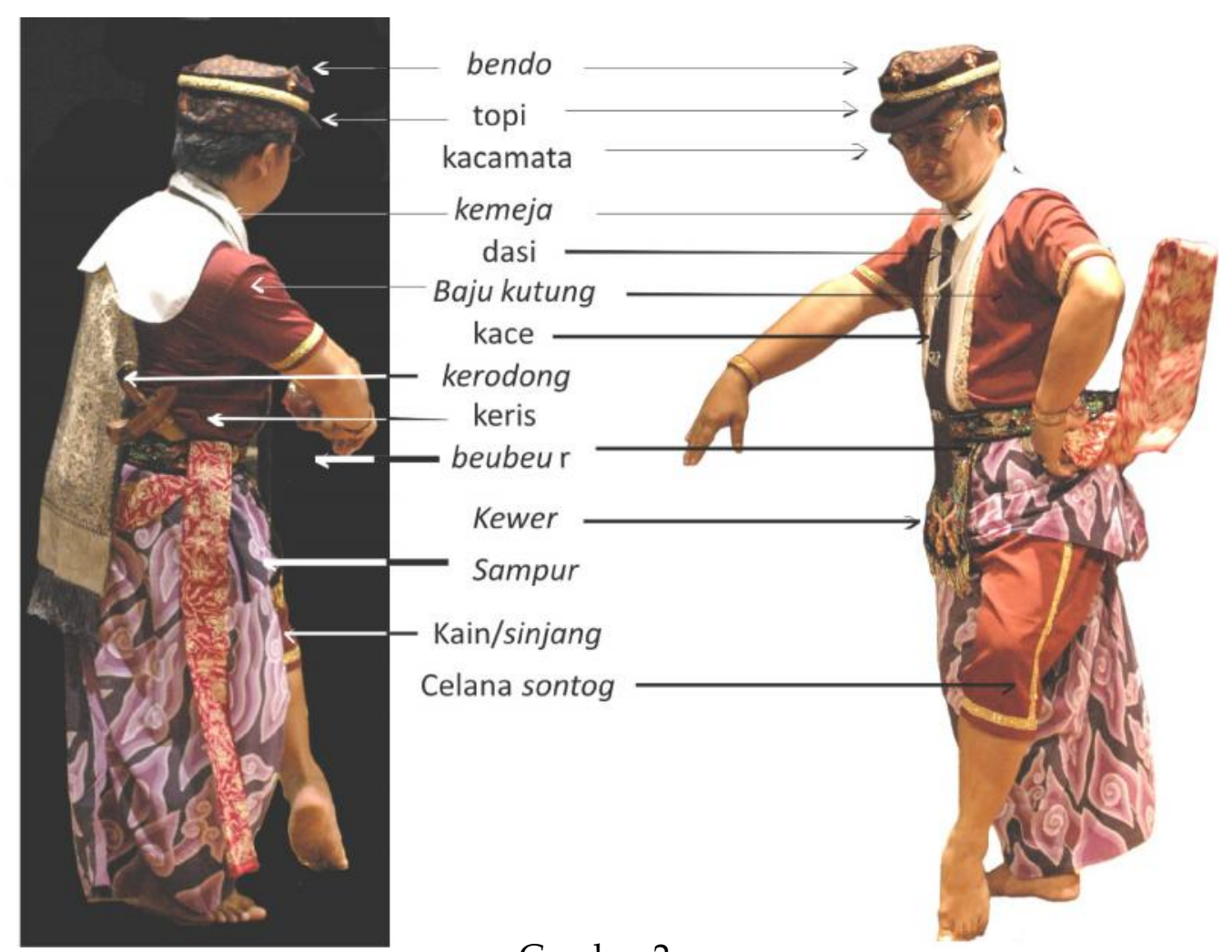

Gambar 2.

Busana Tokoh Tumenggung (tampak depan \& belakang) 
Tabel 1: Pemaknaan Tanda

\begin{tabular}{|c|c|c|}
\hline Elemen Tanda & Deskripsi & Makna \\
\hline \multirow[t]{3}{*}{$\begin{array}{l}\text { bendo/destar, topi, } \\
\text { dan kacamata }\end{array}$} & $\begin{array}{l}\text { Bendo motif batik, kemasan citak, } \\
\text { artinya siap pakai. }\end{array}$ & $\begin{array}{l}\text { simbol } \\
\text { kebangsawananpada masa } \\
\text { feodal / kolonial. }\end{array}$ \\
\hline & $\begin{array}{l}\text { topi wama hitam dengan ornamen } \\
\text { karpatu warna perak: bagian depan } \\
\text { membentuk palang. Bagian atas } \\
\text { bolong, bagian depan menjorok. Di } \\
\text { seputar topi melingkar band warna } \\
\text { mas. }\end{array}$ & $\begin{array}{l}\text { elemen pengaruh barat } \\
\text { (kolonial). }\end{array}$ \\
\hline & $\begin{array}{l}\text { kacamata lensa bening, bertangkai } \\
\text { dan berbidang (frame). Natural, } \\
\text { tanpa sentuhan artistik. }\end{array}$ & $\begin{array}{l}\text { simbol } \\
\text { kepintaran/kecerdasan/ } \\
\text { kein-telekan }\end{array}$ \\
\hline \multirow[t]{2}{*}{$\begin{array}{l}\text { kemeja/klambi gulu } \\
\text { \& dasi }\end{array}$} & $\begin{array}{l}\text { kemeja warna putih, bagian depan } \\
\text { berbentuk segi empat memanjang } \\
\text { ke bawah (dari bahu hingga pusar), } \\
\text { bagian leher diberi aksen kraag } \\
\text { 'berdiri', bagian belakang lebih } \\
\text { menyerupai kraagmarinir yang } \\
\text { dicowak. }\end{array}$ & $\begin{array}{l}\text { simbol } \\
\text { kepintaran/kecerdasan/ } \\
\text { keintelekan }\end{array}$ \\
\hline & $\begin{array}{l}\text { dasi warna hitam, bagian atas } \\
\text { cenderung mengerucut dan bagian } \\
\text { bawah melebar dengan ujung } \\
\text { bawah membentuk huruf V. Di } \\
\text { bagian tengah memanjang ke bawah } \\
\text { tiga buah broach warna perak } \\
\text { sebagai omamen. }\end{array}$ & $\begin{array}{l}\text { simbol } \\
\text { kepintaran/kecerdasan } / \text { kei } \\
\text { n-telekan }\end{array}$ \\
\hline \multirow[t]{2}{*}{ baju kutung \& kace } & $\begin{array}{l}\text { baju wama merah maroon dengan } \\
\text { band melingkar warna mas pada } \\
\text { kedua ujung bagian tangan. }\end{array}$ & $\begin{array}{llr}\text { simbol kebangsawanan } \\
\text { pada masa } & \text { feodal } \\
\text { (Mataram I \& II) } & \end{array}$ \\
\hline & $\begin{array}{l}\text { kace batik warna coklat muda, } \\
\text { terbuat dari lokcan. }\end{array}$ & $\begin{array}{l}\text { simbol kebangsawanan } \\
\text { pada masa feodal } \\
\text { (Mataram I \& II) }\end{array}$ \\
\hline \multirow[t]{2}{*}{$\begin{array}{l}\text { celana sontog\& } \\
\text { kain/sinjang, kewer, } \\
\text { keris }\end{array}$} & $\begin{array}{l}\text { celana warna merah maroon dengan } \\
\text { band melingkar warna mas pada } \\
\text { kedua ujung bagian kaki. }\end{array}$ & $\begin{array}{lll}\text { simbol } & \text { kebangsawanan } \\
\text { pada } & \text { masa } & \text { feodal } \\
\text { (Mataram I \& II) } & \end{array}$ \\
\hline & $\begin{array}{l}\text { sinjang wama dasar ungu tua, motif } \\
\text { mega mendung variasi warna ungu } \\
\text { muda dan putih, dibentuk } \\
\text { menyerupai } \text { dodot. }\end{array}$ & \begin{tabular}{lll} 
simbol kebangsawanan & \multicolumn{2}{c}{ pada masa feodal } \\
(Mataram I \& II) &
\end{tabular} \\
\hline-1 & keris bentuk ladrangan. & $\begin{array}{l}\text { simbol kebangsawanan } \\
\text { dan kepahlawanan pada } \\
\text { masa feodal (Mataram I \& } \\
\text { II). }\end{array}$ \\
\hline
\end{tabular}




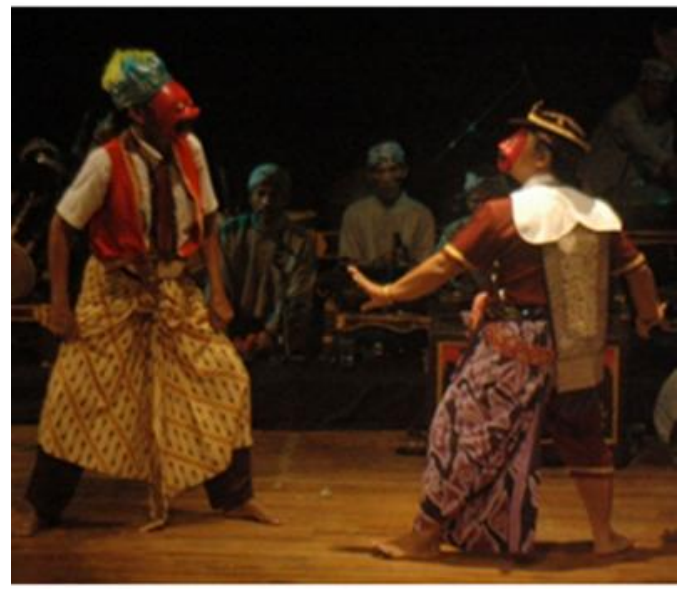

Gambar 3.

Adegan teateral yang menampilkan dialog dan perang antara tokoh

Tumenggung dan tokoh Jinggananom

kace, beubeur, dan gelang tangan. Pada tahap ke dua,busana yang dikenakan mengalami sedikit perubahan (pergantian). jelasnya, menjelang tahap unggah tengah, penari melepas kacamata dan menggantinya dengan kedok. Menjelang tahap akhir, kembali Tumenggung merubah penampilan, yaitu mengganti tutup kepala (bendo dan topi) dengan tekes. Dengan begitu dilihat dari keseluruhan tampilan-nya, tokoh Tumenggung mengenakan busana yang merupakan kombinasi dari busana tradisional dan busana non-tradisional.

Dari gambar 2. di atas kiranya dapat dipetakan elemen tanda berikut pemaknaannya sebagai berikut:

\section{Tipe dan Makna Tanda}

Berdasarkan paparan di atas kiranya dapat dinyatakan bahwa dilihat dari perspektif tipe tanda, busana Tari Tumenggung dimuati kode ganda. Di satu sisi yang menjadi referennya adalah busana tradisional, tetapi di sisi lain menggunakan elemen-elemen kebudayaan non-tradisional, atau dengan kata lain luar elemenelemen dalam paradigma busana topeng.

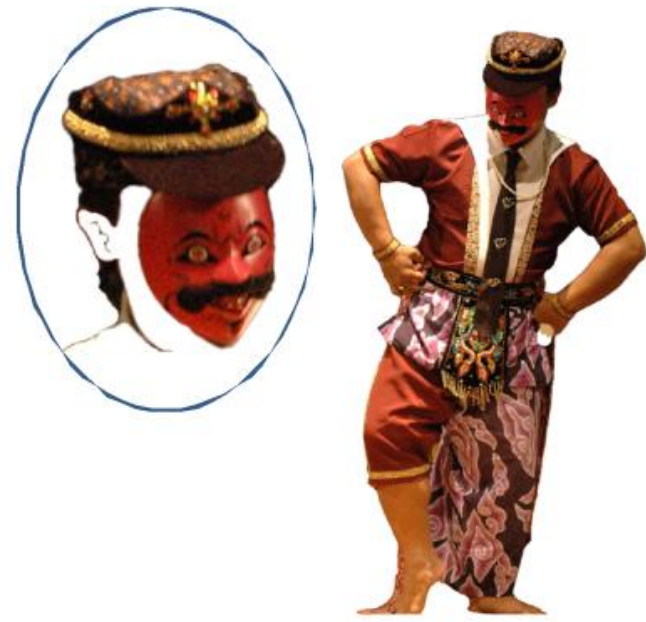

Gambar 4.

Kedokdan Tokoh Tumenggung

Dengan demikian, dilihat dari sudut pandang keilmuan seni, busana Topeng Tumenggung dapat dimasukkan ke dalam bingkai posmodern.

Kemudian dapat dinyatakan bahwa kode ganda yang tergambar pada busana Tari Tumenggung pada gilirannya memiliki makna tertentu. Makna di sini penekanannya pada kebutuhan sosio-budaya. Baju kutung, sinjang, sontog, dan lain-lain merupakan kesatuan yang koheren sebagai busana tradisional keraton. Di sisi lain topi, kacamata, kemeja berikut dasi menunjukkan pengaruh busana Eropa pada masa kolonial. Dengan bergabungnya dua atau lebih tanda dalam paradigma yang berbeda ke dalam satu entitas, maka busana Tari Tumenggung memiliki maknanya yang baru yaitu multikultur.

Munculnya gejala demikian diduga keras dilatarbelakangi oleh satu tujuan atau kepentingan yang tiada lain adalah satir. Jelasnya tokoh yang diciptakan sedemikian rupa dimaksudkan untuk menyindir para penguasa, baik di tingkat pusat maupun di tingkat lokal (khususnya pemuka desa), 
sebagai tokoh yang berpihak pada pemerintah kolonial.

Satir semakin jelas manakala penampilan tokoh Tumenggung dikaitkan dengan kehadiran tokoh Jinggananom. Adapun landasannya dapat diamati dari empat gejala: pertama, pemakaian kedok (Tumenggung); ke dua, aspek penampilan tokoh Jinggananom; ke tiga, isi dialog antara tokoh Tumenggung dengan tokoh Jinggananom; dan ke empat adegan peperangan antara tokoh Tumenggung dengan tokoh Jinggananom.

Pertama, kedok Tumenggung. Sebagaimana telah disinggung di muka, menjelang penampilan bersama tokoh Jinggananom, tokoh Tumenggung hanya melepas kacamata dan menggantinya dengan kedok. Dari telaah estetik bentuk kedokdapat dijelaskan sebagai berikut: warna merah gelap, hidung panjang (bentulan), mata bulat (belotot, thelengan), mulut terbuka sehingga tampak gigi bagian bawah, dan kumis tebal hitam serta membentuk bundaran di ujung kanan-kirinya. Secara tradisional-lokal, bentuk kedok demikian dipakai untuk menggambarkan tokoh yang berwatak kuat dan gagah berani (raja, satria, priyayi), dan tentu saja dengan pembawaan yang'serius'. Dengan menggabungkan elemen kedok dengan elemenelemen busana \& atribut lain sebagaimana tergambar pada penampilan tokoh Tumenggung di atas, maka makna yang diberikan adalah figur yang berkuasa (elit politik) pada masa kolonial. Dan untuk di tingkat pedesaan elit tersebut adalah kuwu(kepala desa).

Proses analisis untuk sampai pada kesimpulan penyebab tokoh Tumenggung dimaknai sebagai tokoh kuwu (penguasa desa) dapat dilihat pada Gambar 5.

Ke dua, penampilan tokoh Jinggananom. Dalam konteks cerita siklus Panji (Damar Wulan, masa Mataram I), tokoh Jinggananom adalah seorang Tumenggung di Jongjola. Pada Topeng Cirebon tokoh Jinggananom tampil dengan mengenakan busana khas, yaitupenutup kepala berupa kupluk, penutup badan atas berupa kaus dan rompi, bagian bawah berupa celana panjang berikut sinjang, sertasampur dibentuk meniru dasi. Dilihat dari telaah estetik bentuk kedok dapat dijelaskan sebagai berikut: warna merah muda, hidung panjang (bentulan), mata bulat

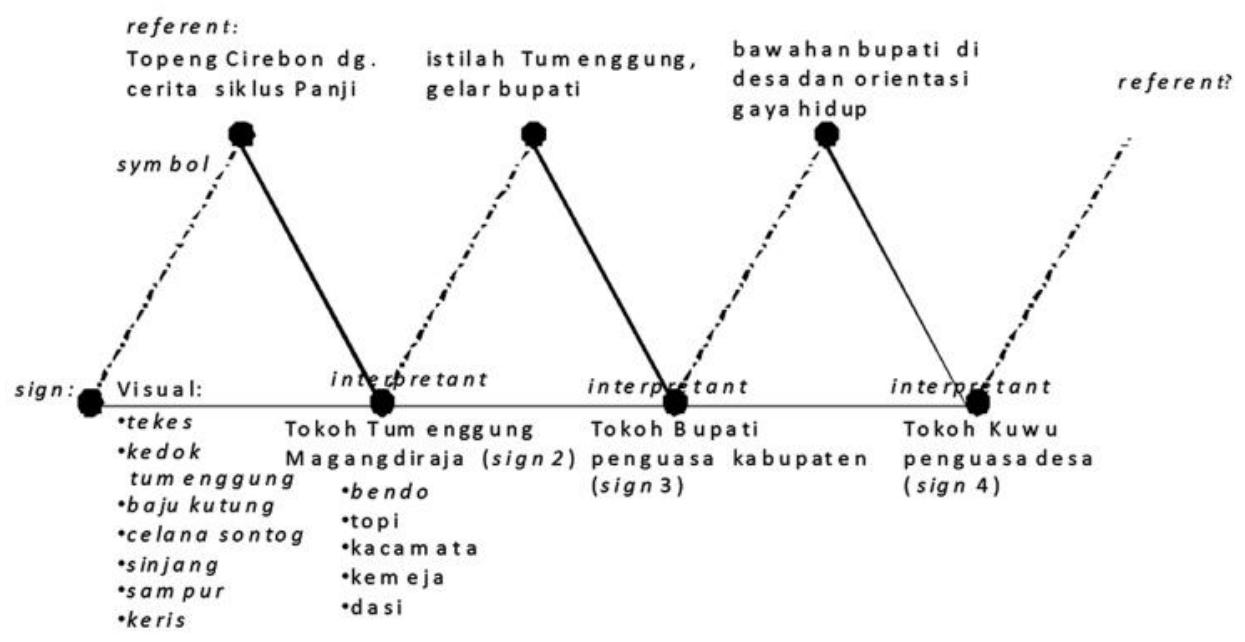

Gambar 5.

Proses Analisis Semiotika Tanda 
(belotot, thelengan), mulut terbuka sehingga tampak gigi bagian atas, dan kumis tebal hitam cenderung tidak rapi. Berdasarkan reka busana\& atribut demikian maka secara kasat mata tampak penampilan Jinggananom 'tidak keruan'. Berdasarkan kondisi ini patut diduga bahwa yang ingin dihadirkan oleh sang kreator adalah kondisi penuh kontras: artinya di satu sisi tokoh Tumenggung ditampilkan serba 'kemilau', maka Jinggananom sebaliknya yaitu terkesan 'berantakan', dan makna di balik berantakan tersebut adalah rakyat jelata.

Berikut ini adalah proses analisis untuk sampai kepada kesimpulan mengapa tokoh Jinggananom dimaknai sebagai rakyat jelata. dapat dilihat pada gambar.

Ke tiga, dialog Tumenggung Jinggananom. Sebagaimana telah disinggung di atas pada tahap ke dua (unggah tengah) tokoh Tumenggung terlibat dialog

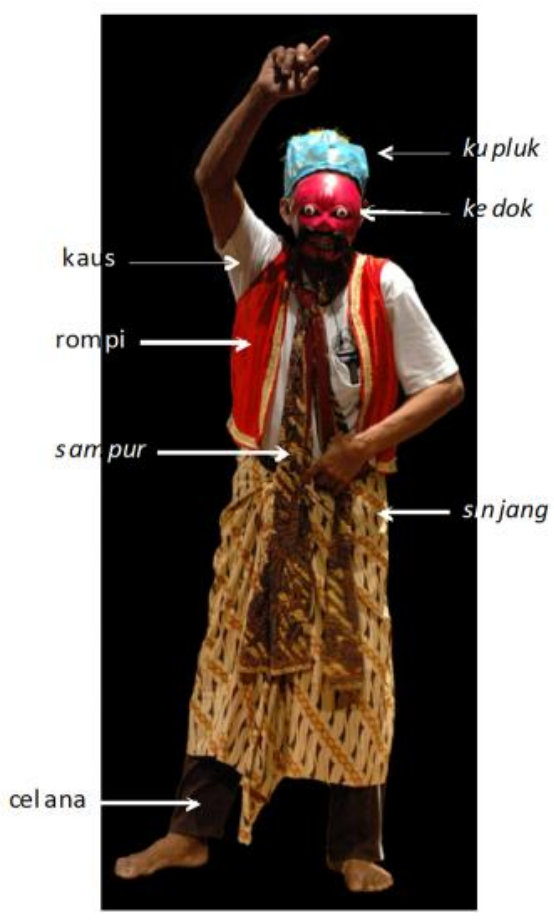

Gambar 6.

Tokoh Jinggananom yang divisualkan 'berantakan'

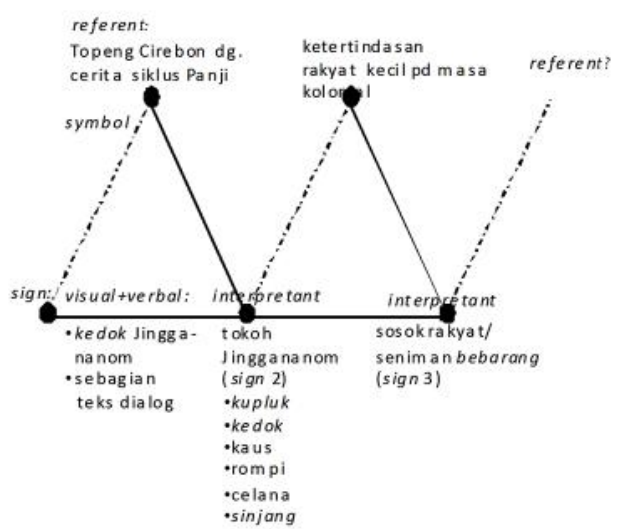

Gambar 7.

Bagan Analisis Tokoh Jinggananom bersama tokoh Jinggananom. Berbeda denganTumenggung yang ucapannya 'didubbing' oleh dalang, maka untuk Jinggananom ucapannya dibawakan oleh Jinggananom sendiriyaitu dengan teknik membuka (sedikit) kedok. Mengapa hal ini terjadi, kiranya dapat dikemukakan alasannya yaitu: tokoh Tumenggung (protagonik) sebagai elit desa perlu menjaga citran dan wibawanya yang oleh sebab itu dia perlu 'dibelenggu' oleh narasi yang diucapkan oleh dalang, di lain fihak tokoh Jinggananom (antagonik) sebagai tokoh yang jelata diberi kebebasan untuk berimprovisasi sehingga bisa menyampaikan uneg-unegnya. Berikut ini adalah sebagian kutipan dialog, yang beberapa kalimatnya beraroma metaforis:

Tmg.: Hii... babu...Jinggananom aja ora pisan pisan. Satekane aku mrene aku diutus kenang Gusti Bawarna kang maksude mertelaken Jinggananom karna wis lawas ora seba ing Bawarna mula saiki. Jinggananom wis gage dandana dina iki uga tindak ing Bawarna.

(Hii... babu...Jinggananom tidak sekali-kali, kedatanganku ke sini, aku diutus oleh Gusti Bawarna yang maksudnya membawa Jinggananom untuk menghadap karena sudah lama tidak pernah berkunjung ke Bawarna. Jadi sekarang juga Jinggananom segera 
berpakaian, hari ini juga pergi ke Bawarna).

Jgn. : Hii... ladalaa... beneerrr awakmu luput tindakane Jinggananom ananging kawruana maring awakmu, apa mulane aku lawas ora seba ing Bawarna, karna aku wis medang skori, artine wis mandiri dewek, wis due Negara dewek aku wis sugih dewek. Aku bli sudi tindak ing Bawarna ila ila jare omonge wong jaman bengen alok jare omong wong jaman saiki Jinggananom wis kaceluk sugih. Sugih ora rerawat miskin ora ulat ulat uga rerawat beras sa nyamplong diorak arik becrit binatang. (Benar anda, salah perbuatan Jinggananom, perlu diketahui oleh anda apa sebabnya aku lama tidak berkunjung ke Bawarna. Karena aku sudah mampu, artinya sudah mandiri. Sudah punya negara sendiri, aku sudah kaya. Aku tidak sudi berkunjung ke Bawarna. Menurut orang jaman dulu, apalagi kata orang jaman sekarang, Jinggananom sudah terkenal kaya, kaya tidak menyimpan sesuatu apapun, miskin tidak mencari apapun juga memiliki beras secangkir diacakacak binatang).

Ke empat, peperangan Tumenggung vs Jinggananom. Dilihat dari sisi gerakan, bentuk gerak kedua tokoh tersebut cenderung pantomim atau sekurang-kurangnya merupakan stilasi dari gerak-gerak keseharian. Namun demikian gerak stilasi tersebut masih dapat dibaca maksudnya karena secara visual memperlihatkan gerakgerak menyerang (ofensif) dan gerak-gerak bertahan (defensif).Akhir peperanganyang dimenangkan oleh Tumenggung (signified) menjadi bukti bawa golongan penguasa mengungguli golongan teraniaya (signifier).

\section{Penguasa vs Rakyat Jelata sebagai Diskursus Kesenjangan Sosial}

Dari paparan di atas kiranya dapat disimpulkan bahwa tokohTumenggung adalah gambaran seorang kuwu(kepala desa, bawahan bupati) pada masa kolonial. Secara visualdan verbal digambarkan berpenampilan gagah, kuat serta berperangai galak. Kemudian Jinggananom adalah gambaran sosok rakyat jelata pada masa yang sama. Secara visual dan verbal digambarkan 'kumuh', lemah serta bersahaja, akan tetapi pandai berdiplomasi, lebih dari itu memiliki harapan dan keinginan untuk hidup layak dan sejahtera.

Demikian, Tari Tumenggung (yang dari perspektif tari merupakan tarian dramatik) pada suguhan Topeng Cirebon dipinjam oleh sang kreator (dalang topeng) untuk menyampaikan sindiran terhadap para penguasa pada masa kolonial. Sindiran tersebut mengerucut pada persoalan kesenjangan sosial: di satu sisi para penguasa hidup bermegah-megahan di sisi lain golongan rakyat hidup kelaparan. Dalam kata lain, Tari Tumenggung adalah diskursus tentang yang kuat menindas yang lemah dan teraniaya.

\section{SIMPULAN}

Tari (Topeng) Tumenggung sebagai karya seni masa lampau telah turut menegaskan salah satu fungsi seni, yaitu fungsi komunikasikhususnya pada tataran promethean, yaitu seni yang dapat meningkatkan moralitas, filsafat, dan pengetahuan manusia (Morawski dalam: Liang Gie, 1996: 50-51). Topeng Cirebon yang sekarang dicap sebagai kesenian tradisional dan kental pakem pada kenyataannya merupakan hasil perubahan secara terus-menerus oleh tangan-tangan terampil (para creator)masa lampau. Berdasar pada anggapan tersebut kiranya dapat ditegas-kan kembali bahwa yang dikatakan kebudayaan (kesenian) tradisional itu adalah dinamis, jelasnya senantiasa berubah, sehingga sulit untuk ditelusuri mana sesungguhnya yang disebut 'asli' itu. Gejala-gejala yang 
sekarang dikatakan tradisional boleh jadi merupakan hasil transformasi pada masa lampau, dan gejala-gejala yang pada masa lampau dikatakan tradisional, juga boleh jadi merupakan hasil transformasi pada masa sebelumnya. Seniman pinggiran yang dipandang rendahan ternyata memiliki ketajaman di dalam membaca situasi sosial, serta memiliki kemampuan di dalam mengekspresikan lewat simbol-simbol seni. Untuk keperluan penyampaian pesan (unek-unek) dan kebutuhan hajat hidup, seniman lampau 'terpaksa' untuk melakukan perubahan terhadap sesuatu yang diterima dari leluhurnya.

Sebagai kata akhir, dari perspektif keilmuan seni, Tari Tumenggung yang muncul sejak masa kolonial tergolong ke dalam parodi dan masuk dalam bingkai postmodern. Bersandar pada anggapan tersebut bilamana pengertian posmodern berfokus pada kode ganda, maka pos-modernisme sesungguhnya sudah lama muncul pada dunia seni pertunjukan masa lampau.

\section{Catatan Akhir}

${ }^{1}$ Dalam cerita Damarwulan sangat mungkin Tari Pamindo menggambarkan tokoh-tokoh Kencanawungu, Damarwulan, atau Anjasmara; Tari Rumiang menggambarkan Layang Seta atau Layang Kumitir, dan Tari Tumenggung menggambarkan Patih Logender.

${ }^{2}$ Di Slangit, Tari Topeng Tumenggung biasa disebut 'tari pecian'. Pertunjukan pada perayaan hajatan biasanya diselingi oleh brimanan atau nyarayuda.

${ }^{3}$ Raja kecil memiliki arti konotatif yaitu penguasa.

${ }^{4}$ Periksa Lubis(1998:190).

${ }^{5}$ Sampai sekarang habitat topeng adalah wilayah pinggiran seperti: Slangit, Gegsik, Losari, dll.

${ }^{6}$ Mengenai istilah gambuh ini rupa-rupanya terjadi pergeseran arti. Menurut Poerbatjaraka (1968: 43) Gambuh (Gambuh Warga Asmara) adalah Candra Kirana yang menyamar sebagai laki-laki untuk mengadakan pertunjukan di kota Gegelang dalam Cerita Panji.

${ }^{7}$ Periksa Nugraha(1982-1983:45)
${ }^{8}$ Negeri (Tumenggungan) Jongjola itu (semula) adalah bawahan Bawarna, tetapi kemudian Jinggananom ingin merdeka, memiliki kedaulatan sendiri, dan karena itu ia tak lagi melakukan seba atau mengirim upeti ke Bawarna (periksa Suanda dalam Nalan, ed. 1996:30).

${ }^{9}$ Diketahui lebih lanjut tokoh Jinggananom tidak ditarikan oleh 'penari' melainkan oleh penabuh gamelan yang secara praktis tidak terampil dalam menari.

${ }^{10}$ Periksa Nurwara, 2012: Penyajian Tari Topeng Tumenggung Perang Jinggananom Cirebon Gaya Slangit . STSI Bandung th, 2012 hlm. 125-127.

\section{Daftar Pustaka}

Agus Aris Munandar

2011 Catuspatha, Arkeologi Majapahit. Jakarta: Wedatama Widya Sastra.

Antlov, Hans, dan Cedderoth, Sven 2001 Kepemimpinan Jawa, Perintah Halus, Pemerintahan Otoriter.Jakarta: Yayasan Obor Indonesia.

Arthur S. Nalan (ed)

1996 Kapita Selekta Tari. Bandung: STSI Press.

Duverger, Maurice

1989 Sosiologi Politik. Jakarta: CV Rajawali.

Fitriastia Nurwara

2012 Penyajian Tari Topeng Tumenggung Perang Jinggananom Cirebon Gaya Slangit . Bandung: STSI.

Gie, The Liang

1996 Filsafat Seni, Sebuah Pengantar. Yogyakarta: Pusat Belajar Ilmu Berguna (PUBIB).

Hardouin, E

1855 Java: Neelen Uit Het Leven, Karakterschetsen en Kleederdragten van Java's Bewoners. 's Gravenhage: K Fuhri.

Kuntowijoyo

1994 Radikalisasi Petani. Yogyakarta: Bentang Intervisi Utama, pt.

Lalan Ramlan

2008 Tayub Cirebonan, Artefak Budaya Masyarakat Priyayi. Bandung: Sunan Ambu Press. 
Lombard, Denys

1996 Nusa Jawa: Silang Budaya 1, Batasbatas Pembaratan. Jakarta: PT Gramedia Pustaka Utama.

Maman Surjaatmadja

1980 Tari Topeng Cirebon dan Peranannya di Masyarakat. Bandung: STSI Press.

Nina Lubis

1998 K ehidupan Kaum Menak Priangan 18001942. Bandung: Pusat Informasi Kebudayaan Sunda.

Onong Nugraha

1982/1983 Tata Busana Tari Sunda. Bandung: Proyek Pengembangan Institut Kesenian Indonesia Sub Proyek ASTI Bandung.

Pigeaud, Th

1938 Javaanse Volksvertoningen, Bijdrage tot de Beschrijuing van Land en Volk. Batavia: Volkslectuur.
Poerbatjaraka

1968 Tjeritera Panji Dalam Perbandingan. Djakarta: Gunung Agung.

Sal Murgiyanto

1982 "Pertunjukan Topeng di Jawa" Majalah Analisis Kebudayaan. Tahun III/No.2. 1982/1983. Jakarta: Depdikbud.

Scherer, Savitri Prastiti

1985 Keselarasan dan Kejanggalan, Pemikiran-pemikiran Priyayi Nasionalis Jawa Awal Abad XX. Jakarta: Sinar Harapan

Toto Amsar

1997 "Tradisi Bebarang Topeng Cirebon", Jurnal Seni No, 12/V/1997. Bandung: Puslitmas STSI Bandung.

Yasraf Amir Piliang

2003 Hipersemiotika, Tafsir Cultural Studies Atas Matinya Makna. Yogyakarta: Jalasutra. 